\title{
Effect of Breadfruit Leaf Powder (Artocarpus altilis) on Number of Blood Cells and Correlation Between Cholesterol Blood and Meat of Tegal Ducks 10 Weeks Age
}

\author{
Elly Tugiyanti* and Emmy Susanti \\ Department of Animal Production, Faculty of Animal Science, University of Jenderal Soedirman \\ Jl. Dr. Suparno 60, Purwokerto 53123, Central Java, Indonesia \\ ${ }^{*}$ Corresponding author email: tugiyanti.elly@gmail.com
}

\begin{abstract}
The purpose of this research was to know the effect of breadfruit leaves powder on number of blood cells and correlation between cholesterol, HDL and LDL of blood with meat cholesterol of male native Tegal duck of 10 weeks old. The material used was day old duck of male Tegal duck as much as 120 heads with experimental research methods and Completely Randomized Design (CRD). There were 6 treatments: feed without breadfruit leaf powder, feed + breadfruit powder $3 \% / \mathrm{kg}$ feed, feed + breadfruit powder $6 \% / \mathrm{kg}$ feed, feed + breadfruit powder $9 \% / \mathrm{kg}$ feed, feed + powder breadfruit $12 \% / \mathrm{kg}$ feed, and feed + breadfruit powder $15 \% / \mathrm{kg}$ feed. Each treatment was repeated 5 times and each replication consisted of 4 ducks. The variables observed were the number of red blood cells, white blood cells, HDL, LDL, blood triglycerides, correlation between cholesterol, HDL and LDL blood with meat cholesterol of male Tegal duck of 10 weeks old. The result of the analysis showed that the supplementation of breadfruit leaves has a significant effect on the number of red blood cells, white blood cells, HDL, and blood triglyceride. There was a positive correlation between blood cholesterol with duck meat cholesterol which given breadfruit leaf powder. This research can be concluded that of breadfruit leaf powder supplementation in feed can increase the number of red blood cells, white blood cells, and blood HDL. However, it decreases blood cholesterol and triglyceride blood of male Tegal duck of 10 weeks old. Cholesterol meat was affected by blood cholesterol with a regression coefficient of 0.78 , influenced by LDL $(r=0.41)$, but negatively affected by HDL $(r=-0.47)$.
\end{abstract}

Keywords: cholesterol, triglycerides, breadfruit leaf, duck performance, duck meat

Abstrak. Tujuan penelitian adalah untuk mengetahui pengaruh tepung daun sukun dalam pakan terhadap jumlah sel darah serta korelasi antara kolesterol, HDL dan LDL darah dengan daging itik Tegal jantan berumur 10 minggu. Materi yang digunakan adalah itik Tegal jantan umur sehari (DOD) sebanyak 120 ekor dengan metode penelitian eksperimen dan Rancangan Acak Lengkap (RAL). Terdapat 6 perlakuan, yaitu: pakan tanpa disuplementasi tepung daun sukun, pakan + tepung daun sukun $3 \% / \mathrm{kg}$ pakan, pakan + tepung daun sukun $6 \% / \mathrm{kg}$ pakan, pakan + tepung daun sukun $9 \% / \mathrm{kg}$ pakan, pakan + tepung daun sukun $12 \% / \mathrm{kg}$ pakan, dan pakan + tepung daun sukun $15 \% / \mathrm{kg}$ pakan. Masing-masing perlakuan diulang sebanyak 5 kali dan setiap ulangan terdiri dari 4 ekor itik. Variabel yang diamati adalah jumlah sel darah merah, sel darah putih, HDL, LDL, trigliserida darah, korelasi antara kolesterol, HDL dan LDL darah dengan kolesterol daging itik Tegal jantan berumur 10 minggu. Hasil analisis menunjukkan bahwa pemberian tepung daun sukun berpengaruh nyata terhadap jumlah sel darah merah, sel darah putih, HDL, dan trigliserida darah. Terdapat korelasi positip antara kolesterol darah dan daging itik yang diberi tepung daun sukun. Penelitian ini dapat disimpulkan bahwa pemberian tepung daun sukun menaikkan jumlah sel darah merah, sel darah putih, dan kadar HDL darah. Namun, pemberian tepung daun sukun menurunkan kolesterol darah dan trigliserida darah itik Tegal jantan umur 10 minggu. Kolesterol daging dipengaruhi oleh kolesterol darah dengan koefisien regresi sebesar 0,78, dipengaruhi oleh kadar LDL $(r=0,41)$, namun dipengaruhi secara negatif oleh kadar HDL $(r=-0,47)$.

Kata kunci: kolesterol, trigliserida, daun sukun, performan itik, daging itik

\section{Introduction}

Currently, cholesterol and triglyceride levels are getting a lot of attention because of some recent research of total cholesterol, low-density lipoprotein (LDL) and high triglycerides in the blood is a major risk factor for Coronary Heart Disease (CHD). However, people's consumption of duck meat for nutritional fulfillment is increasing. As a second line poultry producer of meat after chickens, ducks management has not changed especially in a traditional way 
called umbaran. Performance improvements need to be done so that the quality of the products, especially the meat is safer and healthier.

Feed quality needs attention because feed is one of the important components of growth. Ducks need nutrients to fulfill the physiological processes of their lives. Proper nutrition fulfillment both qualitatively and quantitatively is needed to improve the metabolic yield that can support the development and growth of ducks (Erniasih and Saraswati, 2006). One of the additional feeds that can be used is breadfruit powder.

Breadfruit leaf (Artocarpus altilis) is widely used by Indonesian society as a traditional medicine, because flavonoids, antocyanin, hydrocyanic acid, acetylcholine, tannin, riboflavin, saponin, phenol, quercetin, champerol, $\beta$-carotene, vitamin $\mathrm{C}$ and potassium are efficacious for treatment and functioning as an antioxidant (Maharani et al., 2014; Tugiyanti et al., 2017). Like the human body, the metabolic processes that occur in the body of ducks will naturally produce free radicals. Phytochemical content of breadfruit antioxidants can be utilized for the antidote of free radicals and oxidative stress through various ways, such as by making powder and mixed into the feed (Suryanto and Wehantouw, 2009). Utilization of breadfruit leaves as an additional feed for duck aims to improve the degree of health. Supplementation of breadfruit leaf powder in feed decreases abdominal fat, intramuscular meat fat and meat cholesterol (Tugiyanti et al., 2016). Therefore it is necessary to test the effect of breadfruit flour powder to the number of red blood cells, white blood cells and also need to know the correlation between cholesterol of blood and meat after ducks get breadfruit leaf powder in their feed.

One of the parameters to determine the productivity and health status of livestock was blood profile because blood has an important function in the physiological regulation of the body (Satyaningtijas et al., 2010). Blood is a liquid tissue consisting of two parts, namely blood plasma and blood cells. The overall blood volume is one-twelfth of the body weight. About 55\% are blood plasma, while the remaining $45 \%$ consists of blood cells. (Pearce, 2006). Blood cells consist of red blood cells or erythrocytes (about 99\%), white blood cells or leucocytes $(0.2 \%)$ and blood plasma (Williams, 2007).

Blood has a function as a body transport system that is distributing substances to food and from the cells that make up the body. In addition, blood is also responsible for transporting oxygen from the lungs to all body cells, and then after oxygen is used carbon dioxide is formed which also take will blood to the lungs to be exchanged again with oxygen (Frandson et al., 2009). Pearce (2008) adds that blood also plays an important role in the body's defense system, regulates body temperature and controls the concentration of hydrogen ions in the body, also known as $\mathrm{pH}$ balance. Leukocytes play a role in the cellular and humoral defense of organisms against viruses, bacteria and others. Leukocytes can perform amoeboid movement and through leucocyte diapedesis process can leave capillaries by breaking through endothelial cells and penetrating into connective tissue (Effendi, 2003; Sutedjo, 2006). The utilization of the breadfruit leaves (TDS) in the feed is expected to affect the blood profile and its association with the meat cholesterol.

\section{Materials and Methods}

The study was conducted in a $5 \times 15 \mathrm{~m}^{2}$ experimental cage in the village of Sokaraja Kulon from October to December 2016. There are 30 units of cage with a size of $1 \times 1 \mathrm{~m}^{2}$, which is equipped with a fan, temperature gauge and humidity with litter cage floor. Each cage unit has one long feeding place and one drinking 
place and filled 4 ducks. Litter replaced if wet and clot.

The material used was a day old duck (DOD) of 120 heads with a body weight of $49.54 \pm 2.50$ g, which came from Duck Farmer Group "Itik Umbaran", Desa Negar Ayu, Kec. Tonjong, Kab. Brebes. The ducks selected were ducks whose have same hatching time. Duck weighed to ensure uniformity of body weight. Ducks were fed twice a day and drinking water is provided on ad libitum. Prior to treatment, ducks were fed preliminary feed with $21 \%$ protein content and metabolic energy of $3100 \mathrm{kcal} / \mathrm{kg}$ for a week. Basal feed material consists of $30 \%$ corn, soybean meal $7 \%$, vegetable oil $6.1 \%$, poultry meat meal $17 \%$, bran $38.2 \%$, L-lysine HCL $0.1 \%$, DL-methionine $0.3 \%$, Topmix $0.2 \%, \mathrm{NaCl} 0.1 \%$, and $\mathrm{CaCO} 31 \%$. The ducks were treated for 9 weeks. Feed consumption was observed daily by counting the amount of feed given minus the amount of residual feed. Once a week weighing the body weight to determine the weight gain and at the age of 10 weeks old duck blood sampling through the vein brachialis to observe levels of HDL, LDL, cholesterol and triglycerides.

The research was conducted using experimental method. The design used is Completely Randomized Design. The treatment consisted of six treatments, namely: feed without supplementation of breadfruit powder, feed $+3 \%$ breadfruit powder, feed $+6 \%$ breadfruit powder, feed $+9 \%$ breadfruit powder, feed $+12 \%$ breadfruit powder and feed $+15 \%$ breadfruit powder. Each of treatments was repeated 5 times and each replication consisted of 4 ducklings, so the study used 120 heads of male duck.

The variables observed were the number of red blood cells, white blood cells, HDL, LDL, blood triglycerides, correlation between cholesterol, HDL and LDL blood with duck cholesterol of 10-week-old male Tegal. The collected data were analyzed using variance analysis and if there was effect of treatment then continued with the test of Tukey's Honestly Significant Difference (HSD) (Steel and Torrie, 1997).

The number of red and white blood cells is calculated using the calculated chamber method (Gandasoebrata, 2013). Cholesterol and blood triglyceride levels $(\mathrm{mg} / \mathrm{dl})$ were determined by colorimetric enzymatic methods, and $\mathrm{HDL}$ and $\mathrm{LDL}(\mathrm{mg} / \mathrm{dl})$ analyzes were determined using enzymatic colorimetric methods after $\beta$-lipoprotein precipitation with phosphotungstate and magnesium chloride $\left(\mathrm{MgCl}_{2}\right)$ acids. Levels of $\mathrm{LDL}(\mathrm{mg} / \mathrm{dl})$ were obtained using the Friedewald (1972) formula, namely: $\mathrm{LDL}=$ total cholesterol $-\mathrm{HDL}-1 / 5$ triglycerides. Meat fat content was measured by soxhlet method using ethanol solvent, while the meat cholesterol level was analyzed using Lieberman-Burchard method

Tabel 1. Number of Red Blood Cells (RBC), White Blood Cells (WBC), Blood Cholesterols, HDL, LDL and triglycerides of 10 Weeks Old Male Tegal Duck

\begin{tabular}{|c|c|c|c|c|c|c|}
\hline \multirow[t]{2}{*}{ Variables } & \multicolumn{6}{|c|}{ Level of Bread Leaf Powder in Feed } \\
\hline & $0 \%$ & $3 \%$ & $6 \%$ & $9 \%$ & $12 \%$ & $15 \%$ \\
\hline $\begin{array}{l}\text { Number of } \\
\text { RBC (million } \\
/ \mu \mathrm{l} \text { ) }\end{array}$ & $2.94 \pm 0.31^{\mathrm{a}}$ & $3.63 \pm 0.38^{b}$ & $3.31 \pm 0.31^{\mathrm{ab}}$ & $3.45 \pm 0.33^{a b}$ & $3.40 \pm 0.36^{\mathrm{ab}}$ & $3.45 \pm 0.24 \mathrm{ab}$ \\
\hline $\begin{array}{l}\text { Number of } \\
\text { WBC (cell/ } / \mu l)\end{array}$ & $6030 \pm 666.89^{a}$ & $9350 \pm 540.29^{b}$ & $8630 \pm 804.72 a b$ & $8770 \pm 520.99^{b}$ & $8280 \pm 784.52^{\mathrm{ab}}$ & $9080 \pm 515.51^{b}$ \\
\hline $\begin{array}{l}\text { Total Blood } \\
\text { cholesterol } \\
\text { (mg/dL) }\end{array}$ & $199.71 \pm 18.53^{b}$ & $168.16 \pm 7.98^{a}$ & $174.78 \pm 17.08^{\mathrm{ab}}$ & $168.02 \pm 10.74^{a}$ & $172.39 \pm 9.63^{\mathrm{ab}}$ & $163.91 \pm 8.66^{a}$ \\
\hline $\mathrm{HDL}(\mathrm{mg} / \mathrm{dL})$ & $246.40 \pm 49.28^{a}$ & $299.80 \pm 59.96^{\mathrm{ab}}$ & $301.40 \pm 60.28^{\mathrm{ab}}$ & $314.60 \pm 62.92^{\mathrm{ab}}$ & $294.90 \pm 58.98^{\mathrm{ab}}$ & $349.98 \pm 70.00^{b}$ \\
\hline $\operatorname{LDL}(\mathrm{mg} / \mathrm{dL})^{\mathrm{ns}}$ & $151.27 \pm 46.10$ & $134.35 \pm 23.22$ & $124.63 \pm 19.10$ & $110.42 \pm 31.37$ & $139.70 \pm 35.65$ & $137.06 \pm 26.13$ \\
\hline $\begin{array}{l}\text { Triglycerides } \\
\mathrm{mg} / \mathrm{dL}\end{array}$ & $256.00 \pm 23.85^{b}$ & $231.42 \pm 37.11^{\mathrm{ab}}$ & $246.00 \pm 28.91^{b}$ & $245.33 \pm 22.31^{b}$ & $226.69 \pm 29.48^{a}$ & $229.33 \pm 25.65^{a b}$ \\
\hline
\end{tabular}




\section{Results and Discussion}

\section{Blood Profile of Male Tegal Duck}

The blood profiles observed were the number of red blood cells, white blood cells, blood cholesterol levels, triglyceride levels, total cholesterol, HDL and LDL levels (Table 1).

\section{Number of Red Blood Cells}

The effect of breadfruit powder supplementation into feed against red blood cell count is presented in Table 1 . The average local erythrocytes levels ranged from $2.50 \times 10^{6}$ $\mu l$ to $3.47 \times 10^{6} \mu \mathrm{l}$ (Ali et al., 2013). The number of red blood cells of this research ranged from $2.94 \pm 0.31-3.63 \pm 0.38 \mathrm{million} / \mu \mathrm{l}$, relatively higher than the results of Effendi's (2009) research of 2.46 million/mm2. Schalm (2010), states that the age of erythrocytes in poultry about 28-35 days. The result of variance analysis showed that soybean powder supplementation had significant effect on red blood cell count of male Tegal duck. Based on the result of HSD test, it was found that the number of duck red blood cells that were given control feed was significantly different from duck given breadfruit powder by $3 \%$ in the feed but not different from the number of red blood cells duck fed with powder breadfruit leaves by $6,9,12$ and $15 \%$. Duck's red blood cells are increasing in line with increased levels of breadfruit powder added to the feed.

The process of forming new erythrocytes every day requires a precursor to synthesize new cells. The precursors consist of iron, vitamins, amino acids, and erythropoietin hormones that stimulate the formation of erythrocytes by triggering the production of proerythroblasts from hemopoietic cells in the bone marrow (Meyer and Harvey, 2004).

Breadfruit leaves contain a high enough flavonoid that is $0.88 \%$, vitamin B12 and folic acid (Sikawar et al., 2014; Tugiyanti et al., 2016). Vitamin B12 and folic acid serve to improve the performance of bone marrow, erythroblasts cells in the erythropoiesis process. Vitamin B12 in coordination with vitamin B9 or folate plays a role in the formation of red blood cells and the production of DNA and RNA. In addition Vitamin B12 and folic acid along with vitamin $C, A$ thiamine, riboflavin, pantothenic acid), proteins, and hormones (erythropoietin, androgens, thyroxine) in breadfruit leaves are the substances needed by the bone marrow for the formation of red blood cells ( Morris, et al., 2007).

Sikawar et al. (2014) state that within the leaves of breadfruit there are more than 70 kinds of Phenylpropanoid, nutrients, morin, moracin, dihydromorin, cynomacurin, Flavonoid and others. The presence of flavonoids in the leaves of breadfruit also affects the number of red blood cells of male teal ducks, because the flavonoid is a polyphenol compound that acts as an antioxidant, which in the blood cells can act as a container of hydroxyl radicals and superoxide so protect membrane lipids and prevent damage to blood cells (Sundaryono, 2011; Hong Huey et al., 2013).

\section{White Blood Cells}

White blood cells are blood cells that can form the immune system because it plays a role in fighting various infectious diseases and foreign objects (Isroli et al., 2009). The effect of breadfruit powder supplementation into feed on white blood cells counts is presented in Table 1. Normal white blood cells count (WBC) in ducks is 5520-9110 cells per $\mu$ (Ismoyowati, 2012). The number of white blood cells of this research ranged from $6030 \pm 666.89-9350 \pm$ 540.29 cells per $\mu \mathrm{l}$. The result of the analysis showed that breadfruit powder supplementation into feed had a significant effect on white blood cells count.

Based on the results of HSD test showed that the number of white blood cells given control feed was significantly different from duck which was supplemented by the leaves of breadfruit leaves by $3 \%$, but not different from 
the number of white blood cells duck which was supplemented by the powder of leaves breadfruit by $6,9,12$ and $15 \%$. Supplemented of breadfruit leaves into feed increased the number of white blood cells in accordance with Ridla et al. (2017) study using fermented feed and Ao et al. (2014) using fermented garlic powder.

An increase in the number of white blood cells was caused by breadfruit leaves containing vitamin C and vitamin B (Mustafa, 1998). Chemical content of breadfruit leaves such as saponins, polyphenols, hydrocyanic acids, acetylcholine, tannins, riboflavin, quercetin flavonoids and phenol compounds can be used as a medicine. In addition can be used as a drug compound is antioxidant and able to improve health status (Agustina, 2012). Vitamin C serves to increase endurance, namely increasing the number of white blood cells and the performance of white blood cells or leukocytes (Priestly, 2005). Furthermore, Nurhidayat (2005) adds that white blood cells or leucocytes are involved in humoral and cellular responses. Antioxidants have an important function in the immune system, because the immune system produces free radicals. If the radical level in the immune system goes through the normal level, it will have a negative effect on the immune system. In contrast, antioxidants have the role of capturing free radicals in cells, and enhancing the immune system (Guyton and Hall, 2005; Salvayre et al., 2006). The main function of leukocytes is to damage infectious and toxic materials through the process of phagocytosis (done by macrophages and neutrophils) and form antibodies. Breadfruit powder supplementation improves the health of livestock, because with the high number of white blood cells means the body's defense against infection is getting better. Thus the response of the body in self-defense, ie with the phagocytic immune response, humoral immune response or antibodies and cellular immune responses are also getting better.
Furthermore Asnar (2001) added that the most effective indicator for detecting the immune system is by examining the number of leukocytes circulating in the circulatory system.

\section{Blood Cholesterol}

The effect of breadfruit leaf powder supplementation into feed on blood duck cholesterol levels of 10-week old male Tegal is presented in Table 1 . The average blood cholesterol levels of various types of ducks ranged from $136.7 \mathrm{mg} / \mathrm{dl}$ to $203 \mathrm{mg} / \mathrm{dl}$ (Wahyudi et al., 2013). The amount of blood cholesterol ranged from $163.91 \pm 8.66$ - 199.71 $\pm 18.53 \mathrm{mg} / \mathrm{dL}$. The result of variance analysis showed that soybean powder supplementation into feed had significant effect on blood cholesterol level of Tegal duck at 10 weeks old. Furthermore, the real difference test results showed that blood cholesterol duck given control diet was significantly different from that of duck blood cholesterol whose feed was supplemented with breadfruit powder by 3 and $15 \%$, but not unlike the amount of duck blood cholesterol whose feed was supplied with breadfruit powder 6,9 , and $12 \%$.

Giving breadfruit leaves into the feed increases blood cholesterol levels (Table 1). Breadfruit leaves contain flavonoid compounds, vitamin $\mathrm{C}$ and carotene that can function as antioxidants. These antioxidants, in addition to inhibiting the oxidation process can inhibit the activity of HMG-CoA reductase enzyme in the process of cholesterol synthesis. Inhibition of this enzyme activity leads to the absence of mevalonate from HMG-CoA; mevalonate will be converted into squall, lanosterol, dihyrolanosterol, D 8-dimethylsterol, 7dihydrocholesterol and eventually cholesterol. In addition Flavonoids also have a positive effect on decreased serum total cholesterol levels through increased excretion of bile acids with feces. Bactis leaves contain polyphenols and quercetin $0.88 \%$ (Tugiyanti et al., 2016) which has the effect of lowering cholesterol 
absorption by binding to cholesterol carriers as it passes through the brush border membrane and decreasing the apoB secretion causing a decrease in lipoprotein production.

Breadfruit leaves also contain a high coarse fiber of $15.56 \%$ (Tugiyanti et al., 2016). The high fiber grain feed will cause increased intestinal peristalsis and feed will pass along the intestines too quickly, so nutrient feed is not absorbed optimally (Astuti, 2004). Breadfruits leaves also contain tannin, riboflavin and cyanide acid have a hypoglycemic effect that can lower cholesterol and triglyceride blood of mice (Sulistyaningsih, 2003; Leonard, 2004). Tannin inhibits the absorption of fat in the intestine by reacting with mucosal proteins and intestinal epithelial cells. In addition, tannins can precipitate the protein mucosa on the surface of the small intestine thus reducing the effectiveness of cholesterol and fat absorption. Proteins and amino acids contained in the feed may be precipitated by the tannin contained in the breadfruit leaves so that the absorption of fat from the feed is disrupted. The process causes cholesterol-carrying cholesterol by chylomicrons to the liver in proportion to the cholesterol concentration of the feed (Desmiaty et al., 2008; Wahyudi A. 2009; Liberty et al., 2010).

\section{HDL Blood cholesterol}

HDL is essentially the opposite of LDL; LDL contains a lot of fat, while HDL contains lots of protein. LDL cholesterol levels of duck blood Tegal male 10 weeks old ranged between $110.42 \pm 31.37-151.27 \pm 46.10 \mathrm{mg} / \mathrm{dL}$ (Table 1 ) . The result of variance analysis showed that soybean powder supplementation into feed had significant effect on the increase of $\mathrm{HDL}$ cholesterol level of Tegal duck blood of 10 weeks old. This is due to the presence of flavonoids and vitamin $\mathrm{C}$ that function as an $\mathrm{H}+$ donor, inhibiting 3-hydroxy-3-methylglutaryl coenzyme-A reductase (HMG-CoA reductase) activity and increasing LCAT activity. LCAT is an enzyme that can convert free cholesterol to more hydrophobic ester cholesterol (Stringer, 2008; Aprilia, 2010; Handayani et al., 2017). Then, the cholesterol ester binds to the lipoprotein core particles that make up the new HDL. The antioxidants found in the breadfruit leaves raise $\mathrm{HDL}$ cholesterol levels by increasing the production of ApoA1. Apo A1 serves as a coenzyme cofactor for LCAT as well as a ligand for interaction with lipoprotein receptors in tissues in HDL. Thus, an increase in Apo A1 may increase serum HDL cholesterol levels (Murray, 2009).

\section{LDL blood cholesterol}

LDL cholesterol levels of duck blood Tegal male 10 weeks old ranged between $110.42 \pm$ $31.37-151.27 \pm 46.10 \mathrm{mg} / \mathrm{dL}$ (Table 1). The result of variance analysis showed that soybean powder supplementation into feed had no significant effect on LDL cholesterol level of Tegal duck at 10 weeks old. Breadfruit leaves contain antioxidants that are flavonoid compounds, alkaloids, $\beta$-carotene and tannins. As antioxidants, these compounds have the ability to help lower blood cholesterol levels by binding the bile, but not yet significantly lower LDL cholesterol in the blood, this is because the antioxidants have not been able to lower the basic compounds of cholesterol-forming during cholesterol synthesis in the liver. Low-Density Lipoprotein (LDL) is a lipoprotein fraction of the principal carriers of cholesterols in the blood. Most fatty acids bound to LDL are polyunsaturated fatty acids (polyunsaturated fatty acids). PUFAs are particularly susceptible to oxidation due to their double bonds, and are protected against ROS by antioxidants. The potential antioxidants that protect LDL are $\beta$ carotene because $\beta$-carotene is lipophilic, so it can play a role in cell membranes to prevent lipid peroxidation (Andriani, 2007; Murray 2009). Thus the antioxidants contained in the leaves of breadfruit are more dominant in 
inhibiting the oxidation process of LDL, because compared in inhibiting lipoprotein synthesis, consequently LDL levels that transport cholesterol from the liver to the tissue is still relatively stable. LDL oxidation has some adverse biological effects that produce cytotoxic products and can trigger apoptosis. LDL blood can also be affected by the feed consumed. Feed ingredients used in duck ration of this study include poultry meat meal which is possible affect LDL blood, because LDL has a high lipoprotein cholesterol content and it has lipolytic, so that LDL decrease is not significant.

\section{Triglycerides}

The effect of breadfruit flower supplementation into feed on blood triglyceride levels of Tegal ducks at 10 weeks was presented in Table 1. The average content of blood triglyceride levels ranged from $293.33 \mathrm{mg} / \mathrm{dl}$ to $753.34 \mathrm{mg} / \mathrm{dl}$ (Wijaya et al., 2013). The number of blood triglycerides ranged from $226.69 \pm 29.48-256.00 \pm 28.91 \mathrm{mg} / \mathrm{dL}$. The result of variance analysis showed that soybean powder supplementation into feed had significant effect on blood triglyceride level of Tegal duck at 10 weeks old.

This is due to the content of Flavonoids, quercetin, saponins and tannins in the leaves of breadfruit. Flavonoids increase lipoprotein lipase activity so that it affects serum triglyceride levels (Lamson, 2000). In normal conditions the fat derived from food will undergo digestion process in the intestine into free fatty acids, triglycerides; phospholipids and cholesterol are absorbed into the form of chylomicron (Sari, 2012). Chylomicron will bring triglycerides and cholesterol into the bloodstream. Flavonoids, quercetin, saponin and tannin of breadfruit leaf are the main contents in decreasing triglycerides by increasing LPL enzyme activity by reducing lipid peroxidation (Khakim, 2000). Increased LPL enzyme activity leads to VLDL conversion process to IDL so that the accumulation of VLDL in the liver can be reduced (Xenouli, 2007). In addition, an increase in LPL enzyme activity will also cause triglycerides in chylomicrons to be hydrolyzed to free fatty acids and stored in adipose tissue (Wahyudi, 2009). Citrawidi et al. (2012) adds that blood triglyceride levels are strongly influenced by the circulating levels of free fatty acids in the body. The liver is an organ that is very instrumental in the formation of triglycerides.

\section{Correlation Between Duck Blood Cholesterol and Meat}

The correlation relationship between meat cholesterol with blood cholesterol, blood HDL and blood LDL with correlation coefficient $(r)$ were respectively $0.780941,-0.47022$ and

Table 2. Correlation coefficient and determination between blood cholesterol with duck meat cholesterol with feed of breadfruit leaf powder

\begin{tabular}{lcc}
\multicolumn{1}{c}{ Correlation Cholesterol meat with } & Correlation Coefficient & Determination Coefficient (\%) \\
\hline Blood Cholesterol & 0.780941 & 60.98686 \\
HDL & -0.47022 & 22.11061 \\
LDL & 0.407849 & 16.6341 \\
\hline
\end{tabular}

0.407849 (Table 2). It showed that meat cholesterol level influenced by blood cholesterol $60.84 \%$, influenced by HDL of blood equal to $22.11 \%$ and influenced LDL equal to $16.63 \%$. Meat cholesterol levels were strongly influenced by blood cholesterol levels, and meat cholesterol levels will increase with increasing blood cholesterol levels (Joseph et al., 2002). This is because the body's cholesterol can come from two sources, which comes from food (exogenous cholesterol), and cholesterol produced by the body (endogenous 
cholesterol). If the amount of cholesterol that comes from feed a little, to meet the needs of tissues and other organs, the synthesis of cholesterol in the liver and intestines will increase. Instead, if the amount of cholesterol in the feed increases then the synthesis of cholesterol in the liver and intestines will decrease (Rahmat and Wiradimadja, 2011). Fatty meat is supplied from blood fats.

Simple regression correlation result for meat cholesterol level with HDL of blood there is negative relation with correlation coefficient $(r)$ $=-0.47022$. This is because with decreasing levels of bile salts in the duodenum will result in the liver needs more cholesterol to produce bile salts. Production of bile salts requires cholesterol, if the cholesterol reserves in the liver do not sufficient the HDL will be needed to transport cholesterol from the tissues to the liver and will trigger an increase in HDL levels (Hartoyo et al., 2005). HDL acts as a cholesterol and phospholipid taker present in the blood and passes it on to other lipoproteins to be transported back or removed from the body, thereby affecting the cholesterol of the meat low (Muray, 2009).

Simple regression correlation result for meat cholesterol level with LDL of blood there is positive but very low correlation coefficient $(r)$ $=0.407849$ or only influence about $16.6341 \%$. The amount of cholesterol in cells is governed by two factors: the first factor is the outer cell, such as the amount of free cholesterol or bound in the lipoproteins outside the cell, the free fatty acid supply, and the presence of certain hormones. The second factor is in the cell, such as the activity of the enzyme system that plays a role in cholesterol synthesis and which plays a role in cholesterol catabolism, the amount of tripenoid supply, lanosterol, and squalen as precursors for cholesterol synthesis. Cholesterol d meat can come from two sources, which comes from food (exogenous cholesterol), and cholesterol produced by the body (endogenous cholesterol). If the amount of cholesterol that comes from food a little, to meet the needs of tissues and other organs, the synthesis of cholesterol in the liver and intestines will increase. Conversely, if the amount of cholesterol in the diet increases then the synthesis of cholesterol in the liver and intestines will decrease (Rahmat and Wiradimadja, 2011).

\section{Conclusions}

Breadfruit supplementation (Artocarpus altilis) can increase the number of red blood cells, white blood cells, blood HDL and LDL levels but lowers blood cholesterol and triglyceride blood duck male ten weeks old male. Cholesterol meat is affected by blood cholesterol with regression coefficient $(r)$ of 0.780941 but not negatively affected by HDL $(r=-0.47022)$ and slightly influenced positively by LDL $(r=$ 0.407849).

\section{Acknowledgment}

Acknowledgment to the University of Jenderal Soedirman for research funding which given so the research can be completed writer.

\section{References}

Agustina I. 2012. Efek Estrak Ethanol Daun Sukun Terhadap Kadar Gula Darah Pada Tikus Putih Diabetes Melitus Yang Di Induksi Dengan Alloxan. Program Studi IImu Keperawatan Fakultas Kedokteran-Udayana.

Ali AS, Ismoyowati, dan D Indrasanti. 2013. Jumlah Eritrosit, Kadar Hemoglobin Dan Hematokrit Pada Berbagai Jenis Itik Lokal Terhadap Penambahan Probiotik Dalam Ransum. Jurnal Ilmiah Peternakan 1(3): 1001-1013

Aprilia F. 2010, Aktivitas Ekstrak Etanol Ketan Hitam untuk Menurunkan Kadar Kolesterol, Jurnal Farmasi Indonesia, 5 (2): 63-69.

Asnar ETP. 2001, Peran Perubahan Limfosit Penghasil Sitokin dan Peptida Motilitas Usus Terhadap Modulasi Respons Imun Mukosal Tikus Yang Stress Akibat Stressor Renjatan Listrik, Suatu Pendekatan Psikoneuro-imunologi. Disertasi Program Doktor. Program Pasca sarjana Universitas Airlangga. Surabaya: 102 - 110.

Astuti, 2004. Pemanfaatan Tepung Limbah ikan dalam Ransum Terhadap Kadar Kolesterol Daging 
Ayam Broiler. Proceeding Seminar MIPA UMY, Agustus 2004. Yogyakarta

Desmiaty Y, H Ratih, MA Dewi , R Agustin. 2008. Penentuan Jumlah Tanin Total pada Daun Jati Belanda (Guazuma ulmifolia Lamk) dan Daun Sambang Darah (Excoecaria bicolor Hassk) Secara Kolorimetri dengan Pereaksi Biru Prusia. Ortocarpus 8 : 106-109

Effendi R. 2009. Pengaruh luas kandang dan cara pemberian pakan terhadap beberapa gambaran darah itik Bayang. Universitas Andalas, Padang

Effendi Z. 2003. Peranan Leukosit sebagai Antiinflamasi Alergik dalam Tubuh. Bagian Histologi Fakultas Kedokteran. USU: Medan

Frandson RW, WL Wilke, AD Fails. 2009. Anatomy and Physiology of Farm Animals: 7th Edition. A John Wiley \& Sons, Inc., Publication. Iowa.

Gandasoebrata R. 2013. Penuntun Laboratorium Klinis. Penerbit Dian Rakyat. Jakarta.

Handayani S, Saryono dan Hernayanti. 2017. Effek Daun Alpukat (Persea Americana M.) dan Daun Kelor (Moringa Oleifera L.)Terhadap Peningkatan Kadar HDL Pada Model Tikus Putih Hiperlipidemia. The Soedirman Journal of Nursing 12 (1) : 47-55

Hartoyo B, I Irawan, dan N Iriyanti. 2005. Pengaruh asam lemak dan serat kasar yang berbeda dalam ransum broiler terhadap kandunga kolesterol, HDL dan LDL serum darah. Anim. Prod. 7 (1): 2733

Horng-Huey K, L Wen-Chun, T Cheng-Wei, L ChunChing, Y Feng-Lin. 2013. Prenylated flavonoids from Artocarpus altilis: Antioxidant activities and inhibitory effects on melanin production. Phytochemistry: The International Journal of Plant Chemistry, Plant Biochemistry and Molecular Biology. 89: 78-88

Isnarni E dan E Sulistyani. 2010. Perubahan Jumlah Leukosit Darah Tepi Pada Kondisi Stress Penelitian Eksperimental Laboratories Pada Tikus Wistar Jantan. Stomatognatic (J.K.G. Unej) Vol. 7 No. 32010 : 45-48

Isroli, S Susanti, E Widiastuti, T Yudiarti, dan Sugiharto. 2009. Observasi beberapa variabel hematologis ayam kedu pada pemeliharaan intensif. Seminar Nasional Kebangkitan Peternakan, Semarang, 20 Mei 2009. Hal. 548557.

Lamson, DWMSND and MSND. Brignall. 2000. Antioxidants and cancerlll: Quercetin . Alternative Medicine Review 5(3):196-208.

Liberty PM , SM Sangi, JJE Paendong. 2010. Penentuan Kandungan Tanin dan Uji Aktivitas Antioksidan Ekstrak Biji Buah Alpukat (Persea americana Mill). Jurnal MIPA Unsrat 1(1) : 5-10.

Maharani ETW, AH Mukaromah, MF Farab. 2014. Uji Fitokimia Ekstrak Daun Sukun Kering
(Artocarpus altilis). Prosiding Seminar Nasional Hasil-Hasil Penelitian dan Pengabdian Peran Pangan Fungsional Berbasis Pangan Lokal Dalam Peningkatan Derajat Kesehatan. 9 Agustus 2014. Semarang.

Meyer DJ and JW Harvey. 2004. Veterinary Laboratory Medicine Interpretation and Diagnosis . 3rd Ed. Sauders. USA

Morris MS, PF Jacques, IH Rosenberg, J Selhub. 2007, Folate and Vitamin B12 Status in relation to Anemia, Macrocytosis and Cognitive Impairment in Older Americans in the Age of Folic Acid Fortification,Am J Clin Nutr 2007; 85:193-200

Murray RK, DK Granner, PA Mayes and VW Rodwell. 2009. Biokimia Harper. Jakarta: Penerbit Buku Kedokteran.

Nugroho EJ, Sulastri dan A Maliya. 2013. Pengaruh Pemberian Vitamin C Terhadap Nilai Limfosit Pada Pasien Tuberculose Di Wilayah Kerja Puskesmas Kradenan Kabupaten Grobogan. Fakultas IImu Kesehatan Universitas Muhammadiyah Surakarta.

Pearce, EC. 2008. Anatomi dan fisiologi untuk Paramedis. Cetakan kedua puluh Sembilan PT. Gramedia Pustaka Utama, Jakarta

Rahmat D dan R Wiradimadja. 2011. Estimated Cholesterol Levels Meat and Egg Based on Blood Cholesterol on the Japanese Quail. Jurnal IImu Ternak. 11(1) : 35-38

Salvayre AN, N Dousset, G Ferretti, T Bacchetti, G Curalola and R Salvayre. 2006. Antioxidant and Cytoprotective Properties of High - Density Lipoproteins in Vascular Cells. Free Radical Biology and Medicine 41 (7): 1031 -1040

Wijaya VG, Ismoyowati dan D Mulyadi Saleh. 2013. Study Cholesterol and Triglyceride Levels Blood Of Various Local Duck Feed Supplemented With Probiotics. Jurnal Ilmiah Peternakan 1(2): 661 668

Sari RK. 2012. Pengaruh Pemberian Air Seduha The Hitam Terhadap Kadar Trigliserida Dan Kolesterol LDL Pada Tikus Wistar Yang Diberi Diet Tinggi Fruktosa. Universitas Diponegoro. Semarang.

Schalm. 2010. Veterinary. Haematology. 6th Ed. Blackwell Publishing. USA.

Steel RGD and JH Torrie. 1997. Principles and Procedures of Statistics. Published by McGrawHill Companies, New York.

Stringer JL. 2008. Obat-obat Penurun Lipid Konsep Dasar Farmakologi: Panduan untuk Mahasiswa, Edisi 3, EGC, Jakarta.

Sundaryono A. 2011. Uji Aktivitas Senyawa Flavonoid Total dari Gynura Segetum (Lour) Terhadap Peningkatan Eritrosit Dan Penurunan Leukosit Pada Mencit (Mus musculus). Jurnal Exacta, Ix (2): 8-16. 
Elly Tugiyanti and Emmy Susanti/Animal Production. 19(3):179-188, 2017

ISSN 1411-2027

Sutedjo AY. 2007. Mengenal Penyakit melalui Hasil Pemeriksaan Laboratorium. Penerbit Amara Books. Yogyakarta.

Wahyudi A. 2009. Metabolisme kolesterol hati: khasiat ramuan jati belanda (G.ulmifolia) dalam mengatur konsentrasi kolesterol selular. Skripsi. Program Studi Biokimia. Fakultas Matematika dan Ilmu Pengetahuan Alam. Institut Pertanian Bogor. Bogor. 